\title{
Rebel without Causes: The 1960s Thai Pop Music and Bangkok Youth Culture
}

\author{
Viriya Sawangchot \\ Mahidol University \\ E-mail: tvsawang@gmail.com
}

\begin{abstract}
In this paper, I would like to acknowledge that 1960s to the 1970s American popular culture, particularly in rock ' $n$ ' roll music, have been contested by Thai context. In term of this, the paper intends to consider American rock ' $n$ ' roll has come to function as a mode of humanization and emancipation of Bangkok youngster rather than ideological domination.

In order to understand this process, this paper aims to focus on the origins and evolution of rock ' $n$ ' roll and youth culture in Bangkok in the 1960s to 1970s. The birth of pleng shadow and pleng string will be discussed in this context as well.
\end{abstract}

Keywords: Thai Pop Music, Bangkok Youth Culture, ideological domination 


\section{Introduction}

In Thailand, the Cold War and Modernization era began with the Coup of 1958 which led by Field-Marshall Sarit Tanarat. Consequently, the modernizing state run by military junta, the Sarit regime (1958-1964) and his coup colleague, Field -Marshall Thanom Kittikajon (1964 -1973), has done many things such as education, development and communication, with strongly supported by U.S. Cold War policy and Thai elite incorporating the new landscape politico-cultural power with regardless to the issues of democracy, human rights, and social justice(Chaloemtiarana 1983). The American Cold war's polices also contributed to increasing capital flow in Thailand, which also meant increasing the global cultural flow and the educational rate( Phongpaichai and Baker1997). Between 1961 and 1972, the number of universities expanded from 5 to 17, and the students' enrollment increased from 15,000 to 100,000 . These numbers had dramatic impact on Thai society, as it faced clash of cultures between Western ideas of values, moral standards, fashions and music particularly among the youth. Thus, the growing numbers of youth begun to seek a new frontier of Thai politics and culture(Anderson Mendiones 1985). The applicability of society and state power in the politics and cultural field also became a pressing question. Sulak Sivaraksa, a Buddhist scholar and public intellectual, has mentioned that this period was a turning point that triggered a crisis in "Thainess" (Sivaraksa 1995).

But what the point of the cultural differentiation between before and after 1958 in Thailand, before the 1960s, a full access to western culture was limited to highly educated elite in society. We have to realize that the major politico-cultural power after the 1958 Coup were Modernization and American cultural importation instead of the colonial west and elite culture in the past. It can be noted that cultural and social impacts particularly in entertainment and media culture of Bangkok, the Capital city of Thailand, led to an exchange of values, norms, beliefs, and ideas between Thai and external world markedly (Phuchadapirom 2007, 210-215). At this stage, Thai popular music might be the important point to exam.

Rather than assuming that American popular culture was an attempt to invade Thailand through a pattern of Americanization and cultural imperialism(Bent Huat and Cho 2012)

which managed the successful development of democracies through its political, economies, and consumer culture. Therefore, this chapter aims to examine pleng shadow and pleng string which emerged during these periods shows controversial issues of cultural politics of "Thainess" in Thai society through musical genres, media platforms, and identity. Also I would like argue that pleng shadow music and pleng string are not only musical term but also sociological term.

\section{Pleng Shadow and Days of Being Wild}

In the 1950s, modern Thai popular music was divided into two media discourses, pleng phudi (elite music) and pleang talad (market song), and renamed pleng lukkrung (urban music) and pleng luktung (country music) respectively in the 1960s. Both were heavily influenced by western music. Pleng lukkrung and pleng luktung were associated with particular social or audience groups in the urban and rural areas respectively. Moreover, in terms of national language standardization by the military s broadcasting system such as television and radio,

Central Thai became significantly accepted by most people in Thai society (Reynolds1999). As a result, pleng lukkrung and pleng lukthung which were written and sung in Central Thai were considered as pleng Thai (truly Thai pop music). By 1952, the Public Relation 
Department initially started the Thai TV Chanel 4 and the national radio station (Siriyuvasak 1999 ). As a consequence, it not only helped to boost pleng lukkrung and pleng lukthung being aired more widely but also impacted in the development of new Thai musical genres.

At the same period, the rapid growth of urbanization and modernization was starting to be developed after the WW II. Western pop culture such as Hollywood film, rock 'n' roll music, stylist magazines, fashions etc., had gradually more stream to Bangkok. An interest in western popular music known as "Rock ' $n$ ' Roll" was originally generated by Thai DJs such as U-lan Neungjumnong, Thawan Watthanaputi, in the late of 1950s. At that time, most of Thai DJs were well-educated youth and based in Bangkok. Throughout the 1960s a number of FM radio stations in Bangkok began to air songs sung by British and American bands and artistes.

Ironically, rock ' $n$ ' roll music was largely aired via radio waves in Bangkok area, which were mostly owned by the military. By the early of 1960s "Wong Shadow," became a popular Thai music genre, which was considerably and particularly influenced by British rock bands and artistes like Cliff Richard and The Shadows. Subsequently, the word 'Shadow' was used to refer to Thai bands who have 3 piece music instrument (Guitar, Bass and Drum) as "Wong Shadows" (Eamsa-ard 2006). Louis Guitar Blues was the first Thai shadow band and formed by Chan Kongpasuk and his colleagues from Department of Thai Railway's band. Actually, they played Jazz before turning into rock 'n' roll (Kongpasuk 2013). Louis Guitar Blues' manager, Chan Kongpasuk, was a famous radio DJ and concert organizer who promoted rock 'n' roll popularly among Bangkok youngsters via his radio program. The outcome of such events was the surge in famous Thai shadow bands such as P.M. Pocket, Son of P.M., Silversand, and The Impossible.

It is important to note that the live music during these years was regarded as nightclubs for adult entertainment (Ket-Utuk, Bundasak and Inthrakuk 1964). Most of them were in Sukumvit and Rachadumneon road, Bangkok downtown. The musical genres like rock 'n' roll, jazz, blues were also played by Thai and Filipino bands in hotel lounges, coffee shops, and dance halls. There were few nightclubs that allowed Bangkok youngsters to spend time around with live bands. As a result, Thai shadow performed live shows at occasional ceremony events in temples around Bangkok. Then, some radio DJs and young students started to organize music events in the early of morning (around $6.00 \mathrm{am}$ ) on the weekend at the Theaters, mainly in Wang Burapha area which had three modest theaters. Numerous records and jukeboxes were also available in stores and in street corners throughout Wang Burapha, a new Bangkok downtown at that time.

Bangkok youngsters wanted to explore their identities differing from Thai value. Therefore, rock ' $n$ ' roll, fashion and commodity not only attracted a lot of youths in Bangkok but they were also localized to serve class identities of the youngster. They all modeled themselves after images of American Idols such as Elvis Presley and James Dean have been hit in Thailand in the late of 1950s; the boys did their hair like James Dean and the girls wore skirts like Hollywood film stars. Most importantly, from the late of 1950 onwards, some groups of Thai adolescents who reigned over Wang Burapah split up into a group and started to call themselves "Go Lang Wang"( Youngster who hang around Burapah Palace). Some of them, who always hung around there, begun to identify themselves as alias of commodity such as Dang Bireley, Dum Esso, Kieng Union and Josh Howdy etc,.

Though Go Lang Wang was masked by gangster and American expression, they challenged the moral and the ideology of military state with their styles. By the consumption of American 
popular culture, they were setting their identities to criticize Thai modernity trajectory. At that time, emotional energies of rock ' $n$ ' roll themselves initially can serve to building around everyday lives of Bangkok youngster that so-called "Go Lang Wang", to them rock 'n' roll was not just music, but also served to build in - group solidarity powerfully. The media discourse of Go Lang Wang blamed them as "not a good Thai". By consuming American rock ' $n$ ' roll that made the common the attitude towards the rock 'n' roll and its culture marked off the Go Lang Wang generation more radically than any other previous generation. Go Lang Wang always fought with other youngster group. But the events became critical issues when

youngsters got into fight with other groups. Then, these group were labeled as criminal gang law or "Anthaphan" ( bad guys) by military law in Sarit regime (Chaloemtien 1983).

More practically, there are some aspects that police used to identify Go Lang Wang style as Anthaphan (1) wearing red shirt (2) wearing fit pant (3) hanging round the public space more than 5 persons (4) using too much hair oil (5) showing the comb (Krungkasem 2003). Due to these cases, The Thanarat's military government condemned an influence of American rock ' $n$ ' roll under the pretext of safeguarding traditional Thai identity and wanted to normalize this influence on Thai youngsters. Around 200 youngsters were arrested by this law and released in 1964 after Thanarat's death. Nevertheless, the Thai government indirectly supported the String Combo band contests, which were organized by the Music Association of Thailand under the royal patronage of King Bhumibol (Emmsaard 2006). By the mid-1960s, Bangkok youngsters desired something new in the music scene. As a result, Pleng String was born. Thus, pleng string emerged as a result of the fusion among government's regulation, moral panic and youngster's new desire.

\section{From Wong Shadow to String Combo}

In 1969, The String Combo Band Contest of Thailand was organized by the Music Association of Thailand under the royal patronage of King Bhumibol. In the first contest, besides Western pop songs, every band had to play songs composed by the King. The winner of the music contest would receive the King's trophy. This contest symbolized the relevance of music in Thai culture, particularly in string combo. The showdown band( four-piece band) were not allowed to perform anymore. As a consequence, wong shadow started to disappear from the music scene or voluntary transformed to string combo (guitar band with brass). Ironically, though American rock ' $n$ ' roll music was loved by Thai youngster but Government Thai and elite condemn rock 'n' roll coined as Shadow music. Then, string combo was born to represent a new stage of revolution among Thai popular music, authentically Thainess, and urban youth culture. Most of string combo musicians were young people who were keen to seek new social values and the transformation of society in an equitable manner.

The Impossible, the band who won the first string combo contest, was the first Thai pop band to write and arrange their own songs in Thai. The five-piece band but their members were up to 10 persons. They wrote and arranged film soundtracks such as Tone(1969), Nueng Nuch(1970), Rareung Chon(1971). The Impossible was a nightclub band playing in many hotels' nightclubs along Petchaburi road, the new venue of Bangkok nightlife for American soldier who took a break for their war duty in the 1970s. As a result, the band was also known for its cover the 1970s western pop music from rock to soul. They rereleased their first all-Thai lyric album, Penpai Mai Dai, in 1972 and all- English lyric album, Hot Pepper, in 1975(Cover Kool and The Gang's two songs, Give it Up" and "Love the Life You Live"). The band 's hit songs included "Thalay Mai Khoey Lap" ("Seas never sleep"), "Rak Chua Niran" ("Love forever"), "Khoy Nhong" ("Waiting for you"), "Nueng Nai Duang Jai" ("Only 
one in my heart") and "Penpai Mai Dai" ("Impossible").The Impossible 's songs emphasized the daily lives and romances of ordinary people's which were familiar to the urban youth. Young audience could easily identify with these songs and differentiate their identities and musical taste from those of the elite who favored pleng lukkrung. The band broke up in 1977 after spent the time playing nightclubs in Hawaii(1974) and Germany(1975-1976), but has frequently performed at reunions over the years.

In 1973, the end of the authoritarian period was marked by Thanom's resignation, following a people uprising of pro-democracy protesters led by Thammasat students in Bangkok. Therefore, in order to achieving freedom in the political and cultural live of the people, pleng pua chiwit (Song for life) invited new musical styles in Thai popular music with hybrid music forms of American folk song and Thai folk music. Form this position, it can be debatable whether their achieve coming out of the different of political ideology and artistic autonomy between pleng string and pleng pua chiwit. Trying to size the power elite pleng pua chiwit goes to the lower classes and the peasant because they have been robbed of their rights. In a different way, pleng string takes up the plight of the new middle class whose taste has

been robbed by elite class. But, without democratic system and de-regulation of media, they could not take up their voices cause as part of national agenda. Then, most of pleng pua chiwit singers were born to student activities while string combo band were born to serve nighttime entertainment.

However, the most successful of Wong String (the band who plays Pleng String) in the history of Thai popular music is Grand Ex, the band who won a junior award in the third year of The String Combo Band Contest of Thailand in 1972. The band came late and had not many experiences in nightclub scenes both in Bangkok and in other parts of Thailand. Their famous came from their show with eight- piece bands (two guitars, one bass drum, three brass and two keyboards) in Bangkok nightclub with sounds frequently crossing into funk, R\&B, pop and folk. The band released their first album, Khru Nok, in 1975 with a little success. In

1979, the band Grand Ex made a recording of the album "Lukthung Disco" where it brought pleng lukthung to play in the disco musical style. There were hugely successful with total sale of more than 1,000,000 copies (released on cassette) for each, which were the highest album sales in Thailand at that time. Lukthung Disco II released in a following years with a hugely successful again. Two years later, Grand Ex made an album titled "Grand Ex 0" which used pleng lukgrung compositions re-arranged and played in pop rock style. It was also highly successful again(Weerayan 2010: 71, 102). The band 's hit songs included "Thalay Mai Khoey Lap" ("Seas never sleep"), "Tas Lak" ("Slave to Love "), "Khoy Nhong" ("Waiting for you"), "Bua Noi Kloy Rak" ("Young Girl waits for Her love") and "Kern" ("Shy ").The success of their music writing and arranging in Thai inspired other string combo bands to follow suit. Many old

string bands such as Royal Sprites, McIntosh and the Presidents released their Thai albums rearranging pleng luktung and pleng lukkrung with western pop music. The lyrics of pleng string released at that time were considered realistic issues as they wrote on romanticism and hedonism. However, pleng string began to decline in popularity in the late of 1980s when the music industry and broadcasting media in Thailand were under control by new pop and dance music of the Thai major labels such as Grammy and RS Promotion.

\section{Depoliticizing the Rock Formation and Cold War Culture}

As American scholar Lawrence Grossberg (1992)notes that rock is perhaps the only musical culture in which the identity of its audience bleeds into the music. He also coined the 
concept rock formation, connoting rock's broad cultural context and associations, which has become central to contemporary society. However, Simon Frith (1996), a prominent British popular music studies scholar, contends that musical styles during the Americanization era, particularly in non-western countries could take many forms and have various effects,

some of which might be diametrically opposed to the original source. As we have seen above, pleng shadow and pleang String, from the late of 1960s onwards, both were perceived as subversive and had become a staple of the formation of rock music among young Thais. In the context of pleng shadow, it represented a state of revolution in Thai popular music culture, identity politics of urban youth culture under the military regime and the influence of American popular music. In addition, emotional energies of rock 'n' roll themselves can serve to building around everyday politics of Bangkok youngsters, to them rock ' $n$ ' roll was not just music, but also served to build in - group solidarity powerfully such as Ko Lang Wang. Their attitude towards the rock 'n' roll marked off their behavior more radically than previous generation anything else.

Stuart Hall(1996) noted that a cultural practice does not carry its politics with it, as if it inscribed as a consequence of the ways in which, in a particular conjuncture, it is articulated to other practices. Therefore, the conflict over American influences on politics of identity and popular music culture are arenas of contest and negotiation within changing relations among Thai value, new generation and everyday politics. In other word, pleng shadow become more and more similar to western music popular music, particularly in not rock music but it was not accepted by the elite and ruling classes as aliened culture and non-Thai. Ironically, though American rock ' $n$ ' roll music was loved by Thai youngster but Government Thai and elite condemn. It seems pleng shadow uses their sound and its culture to send political message to elite and military junta calling for their right to live culturally. In the context of pleng string, it became closer to the music of common people with melody and lyric in popular music style. Singing styles and lyrical contents still preserved the identity of the young generation in transitional period from undemocratic to democratic society without politics message. Pleng string takes up the plight of the middle class whose taste has been robbed by elite class. Most of pleng string musicians were young people who were keen to see new social values and the transformation of society in an equitable manner. Their music thus captured the daily lives and romances of ordinary people.

Although these musical styles differed the audiences were the same, comprising mostly of university students and new middle-class youths at that time. Generally, Thai popular music such as pleng lukkrung and pleng lukthung falls into the conservative concept of a centralized authoritarian state, for citizens and public are excluding from participant in a freedom of communication and the public sphere( Siriyuvasak1999). Having appropriating Americanization, the evolution of pleng shadow and pleang string demonstrated the struggle for the changing political ideologies as well as everyday politics of Thai society in the transition period from military regime to democracy.

Therefore, in order to achieving freedom in the political and cultural live of the young generation in the 1960s onwards, pleng shadow and pleng string invited new musical styles in Thai popular music with different music forms. Form this position, it can be debatable whether their achieve coming out of the different of political will and artistic autonomy. The most important point is that pleng shadow and pleang string were transformed from being music for the young label to one for the common audience in Thailand. The process of adoption of musical genre and commercialization of pleng string began in the late of 1970s after pleng shadow musician faded away or transformed to other music genre voluntary. In 
a different way, without a democratization of political structure and everyday politics, both could not take up their voices cause as part of national popular music.

\section{Concluding remarks}

In the case of pleng shadow and pleng string, we can say that rock formation and it culture have also existed and localized in non-western societies like Thailand in the 1960s onwards. They were immune from the influence of Americanization and its rock music culture (or formation) which became localized to emancipation of Thai youngster just after its birth. In other words, the popularity of pleng shawdow and pleang string represented the conflict between traditional and progressive values of Thai society in the 1960s to 1970s. I think this study of musical genre also provides significant information on the relation between the origins of youth culture and formation of ideology rock culture in Thailand as argued by both Grossberg and Frith. However, the research on identity politics and popular music in Cold War in Thailand in general, is still by and large neglected by most Thai studies scholars. More work must be done in this area. I think there is something to be clearer among "Americanization", "AntiAmerican" sentiment, and politics of counter-culture in Cold War era of Thailand. 


\section{References}

Anderson, B.and Ruchira Mendiones. (1985). In the Mirror: Literature and Politics in Siam in American Era. Bangkok: Duang Kamol Publishing.

Bent Huat, Chua \& Younghan Cho.(2012). "Editorial Introduction:American Pop Culture". Inter-Asia Cultural Studies Journal.Vol.13 No.4, 2012.

Chaloemtiarana, T. (1983). KanmuangRabobPokumOppatham Bab Taharn.( Thailand : The Politics of Despotic Paternalism). Bangkok :Thammasat University Press.

Emmsa-ard, L. (2006). Thai Popular Music: The Represent of National Identities and Ideologies within a Culture in Transition, PhD Dissertation, Edith Cowan University.

Frith, S. (1996). Performing Rites: On the Value of Popular Music. London: Oxford University Press.

Grossberg, L (1992).We Gotta Get Out of This Place. Popular Conservatism and Postmodern Culture. New York: Routledge.

Ket-Uteuk, P., Sarn Bundasak and Kriet Inthrakuk.(1964). Bangkok Nightlife. Krungthon Publication.

Krungkasem, P.(2003). Pu's Way. Bangkok: H.A. Publication.

Kongpasuk, K.(2013). Personal interviewed. 13/10/2013.

Puchadapirom, P.(2007). Watthanatham Buteung Ni Pratet Thai Rawang1948-1957. Bangkok:Matichon.

Sivalak, S. (1991).'The Crisis of Siamese Identity'In Reynolds, C. (Ed.), National Identity and Its Defender. Chiang Mai: Silkworm.

Phongpaichai, Pasuk and Chris Baker (1997).Thailand : Economy and Politics. London:Oxford University Press.

Reynolds, C. (1999). National Identity and Its Defender. Craig (Chiang Mai: Silkworm).

Siriyuvasak, Ubonrat. (1999). Sethasatkanmuang klong rabob witthayu Thai kab ponkataob tor sithi manusayachon. (The Political Economy of Thai Broadcasting System and Its effect to Human Life). Bangkok: Chulalongkon University press.

Wuttipong, N.(2011). The Thai Popular Music Industry: Industrial Form and Musical Design, PhD Dissertation, The University of Nottingham. 